\title{
REGISTRO FOTOGRÁFICO E A DINÂMICA DAS NEGOCIAÇÕES NA CONSTRUÇÃO DA ETNOGRAFIA: MINHAS EXPERIÊNCIAS COM A PESQUISA "BONECAS KARAJÁ"
}

\author{
Telma Camargo da Silva ${ }^{1}$ \\ PPGAS-FCS-UFG
}

\section{A diluição dos limites entre autorização, capacitação e devolução de imagens fotográficas $^{2}$}

A produção de fotografias em pesquisas que subsidiam a patrimonialização de bens culturais produzidos por sociedades indígenas aponta para a indissociabilidade entre a autorização para captação de imagens, a sua produção e devolução. A experiência em campo, como integrante da pesquisa coletiva ${ }^{3}$ Bonecas Karaja $^{4}$ : arte, memória e identidade indígena no Araguaia, executada no Museu Antropológico da Universidade Federal de Goiás - UFG -, evidenciou que o consentimento para 'ser fotografado/a" ultrapassa as formalidades definidas pelos órgãos reguladores ${ }^{5}$ da pesquisa e vai além das assinaturas, pelos sujeitos coletivos e individuais, dos Termos de Consentimento Livre e Esclarecido (TCLE), requerendo uma contínua negociação. Meu argumento é de que as fases de autorização, captação e devolução de fotografias muitas vezes se fundem, dão origem a um tipo particular de negociação que engendra um processo que assegura, facilita ou dificulta o próprio trabalho de campo.

Se a tradição da pesquisa antropológica demonstra que as negociações e as reciprocidades, os dons e os contra-dons (Mauss, 1966), as traduções de universos

\footnotetext{
${ }^{1}$ Universidade Federal de Goiás, Brasil.

${ }^{2}$ As imagens fotográficas usadas nesse artigo são de autoria de Telma Camargo da Silva e pertencem ao acervo do Instituto do Patrimônio Histórico e Artístico Nacional - IPHAN.

${ }^{3}$ A equipe de campo foi composta pelo antropólogo Manuel Ferreira Lima Filho e pelas antropólogas Nei Clara de Lima, Rosani Moreira Leitão e Telma Camargo da Silva. O projeto foi financiado no ano de 2008 pela Fundação de Apoio à Pesquisa do estado de Goiás (FAPEG), e recebeu a apoio da Secretaria de Estado de Políticas Públicas para Mulheres e Promoção da Igualdade Racial (SEMIRA). Em 2010, o projeto contou com a parceria e financiamento do IPHAN. A pesquisa foi desenvolvida no período de novembro de 2008 a agosto de 2011. A segunda fase da pesquisa $(2010$ - 2011) esteve sob minha coordenação.

${ }^{4}$ Ritxoko na fala feminina.

${ }^{5}$ A pesquisa em terras indígenas e a captação, uso e reprodução de imagens indígenas são regulamentadas pela Instrução Normativa Fundação Nacional do Índio - FUNAI, nº1 de 29 de Novembro de 1995 e pela Portaria $n^{\circ}$ 177/PRE, de 16 de Fevereiro de 2006. De acordo com estas regulamentações, um projeto de pesquisa além de receber a autorização expressa dos titulares do direito de imagem, deve receber parecer favorável do CNPq quanto ao mérito da pesquisa e ser submetido para análise junto à Coordenadoria Geral de Estudos e Pesquisas da FUNAI. No caso da Universidade Federal de Goiás, que requer a obrigatoriedade de submissão dos projetos de pesquisas ao Comitê de Ética em Pesquisa (CEP) para que o mesmo seja cadastrado e assim ser legitimado como produção acadêmica de seus docentes, o projeto Bonecas Karajá passou por mais este trâmite burocrático.
} 
culturais distintos e a vivência da alteridade são características intrínsecas ao exercício do ofício antropológico, isto se torna mais evidente nas pesquisas que objetivam a patrimonialização de bem cultural indígena e a produção da documentação ${ }^{6}$ audiovisual, que subsidia os pedidos de registro. Isto porque o que está em jogo desde o início é o próprio sentido de patrimônio e a lógica subjacente a duas formas de conhecimentos: um saber tradicional - no caso o ofício e o modo de fazer Ritxoko - e a sua tradução para um saber sistematizado segundo a racionalidade de uma agência de preservação - o IPHAN, ambos mediados pelo trabalho antropológico. Como analisei em outros trabalhos (Silva, 2012 a; 2012 b), o conhecimento sobre o modo de fazer a boneca cerâmica Karajá está entrelaçado nas histórias locais sobre brincadeiras infantis, nas narrativas femininas de atribuições de gênero, na reprodução material do imaginário mítico. Mas também nas mãos das oleiras e no cuidadoso fabricar de cada um dos artefatos. Logo, as narrativas estão além da oralidade ${ }^{7}$, provocam a sensibilidade do olhar por parte do/da antropólogo/da e o exercício de outras formas de construção de dados, como o uso da fotografia. É nesse contexto de múltiplas traduções e negociações que a captação de imagem adquire uma especificidade que merece uma descrição ${ }^{8}$ e alguns apontamentos para análise.

\section{Planejamento para captação de imagens fotográficas, construção do diário iconográfico e o surgimento de tensões}

A inserção em campo da equipe de pesquisa do projeto Bonecas Karajá e, posteriormente, da equipe de filmagem - Olho Filmes - seguiu as orientações canônicas disciplinares: reuniões para apresentação do projeto; conversas sobre "patrimônio" com

\footnotetext{
${ }^{6}$ A documentação que subsidiou o Registro das Ritxoco junto ao IPHAN é formada por um texto etnográfico (Lima et al., 201), um conjunto de 3.156 imagens fotográficas digitalizadas e dois vídeos etnográficos de $18^{`}$ e $45^{`}$ minutos respectivamente (Borges, 2011). Esse pedido foi apreciado e aprovado pelo Conselho Consultivo do IPHAN em 25 de janeiro de 2012.

${ }^{7}$ A maioria das ceramistas das aldeias pesquisadas na Ilha do Bananal (TO) - Santa Isabel do Morro, JK, Wataú e Werebia - não é falante da língua portuguesa. Dibexia e Terraluna, da aldeia Santa Isabel do Morro, participaram como auxiliares de pesquisa. Eles atuaram como intérpretes entre as duas línguas usadas - Inyrubé e Português e tiveram participação importante na tradução e, muitas vezes nas negociações para o esclarecimento sobre o sentido de "patrimônio" e sobre a assinatura do TCLE.

${ }^{8}$ A captação de imagens fotográficas que compõem o dossiê que subsidiou o registro dos "Saberes e práticas associados aos modos de fazer bonecas Karajá" e "Ritxoko: expressão artística e cosmológica do povo Karajá" foi feita por Telma Camargo da Silva, Rosani Moreira Leitão, Nei Clara de Lima, Manoel Ferreira Lima Filho e Raíssa Ladeira. Do total de 3.156 fotografias produzidas e entregues ao IPHAN, 810 imagens são de minha autoria e foram realizadas durante oito viagens para pesquisa de campo nas aldeias Buridina e Bde-Buré (Aruanã - GO); Santa Isabel do Morro, JK, Watau e Werebia (Ilha do Bananal - TO). Este texto apresenta uma reflexão sobre a minha experiência pessoal como antropóloga em campo e não sobre o conjunto do trabalho executado pelos outros integrantes da equipe.
} 
entrega dos livros publicados sobre outras referências culturais registradas ${ }^{9}$ (imagem 01); respostas às insistentes perguntas em torno da questão: $O$ que nós Karajá ganhamos com o "registro da boneca ?"; a assinatura dos termos de autorização para a realização da pesquisa (imagens 02 e 03 ) e , de formulários para a captação de imagens e sons (imagens 04 e 05).

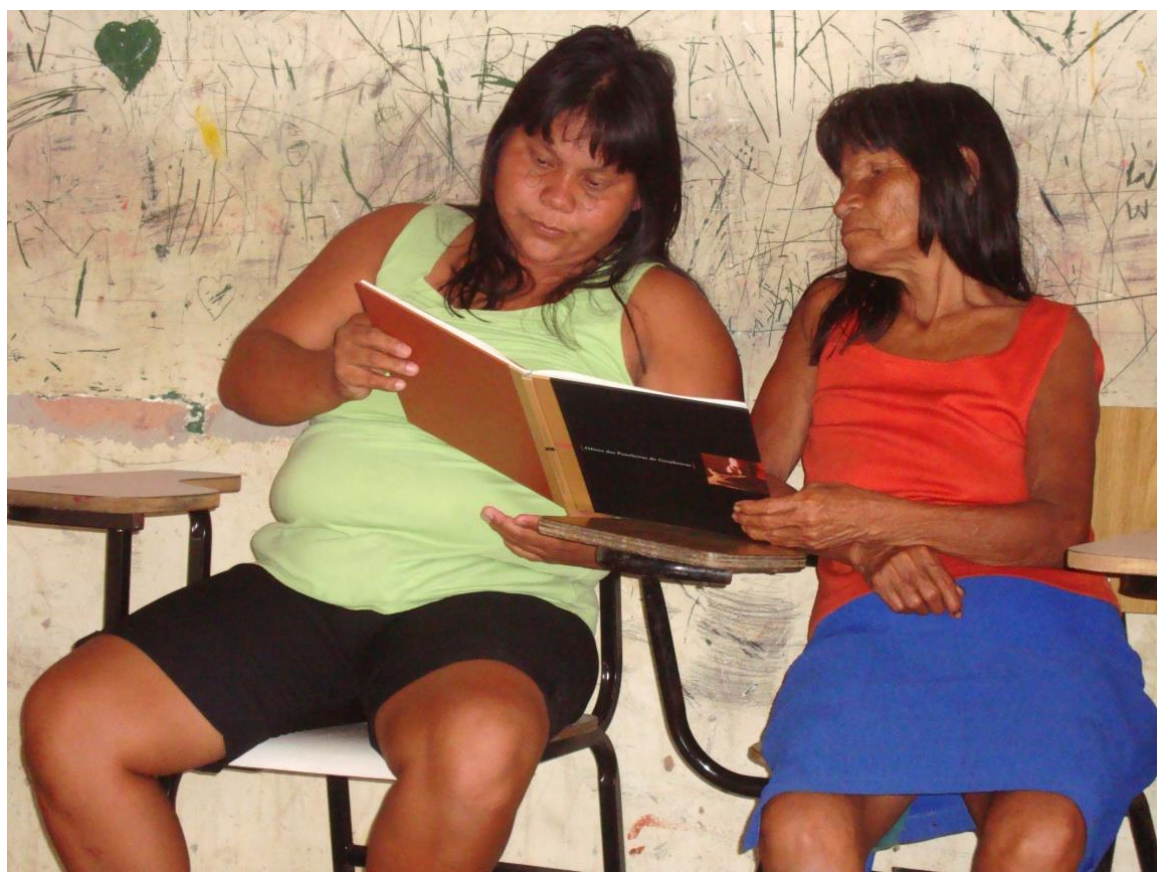

Imagem 01 - Ceramistas de Santa Isabel do Morro durante a reunião para apresentação do projeto e entrega de livros de referências culturais já registradas no IPHAN.

\footnotetext{
${ }^{9}$ Por exemplo, o Dossiê 2 - Arte Kusiwa-Pintura corporal e arte gráfica Wajãpi. 2008.
} 
Telma Camargo da Silva
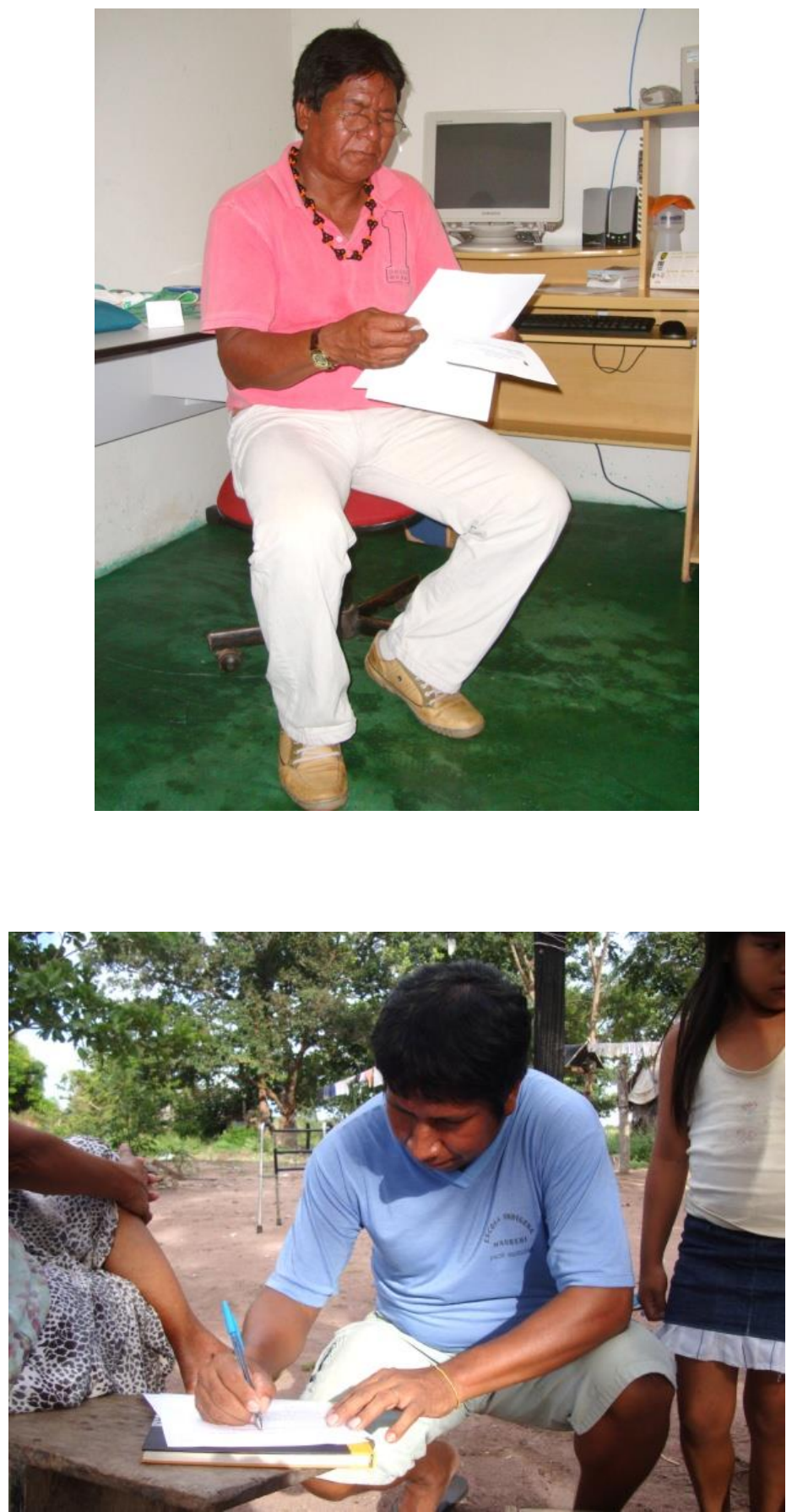

Imagens 02 e 03 - O cacique Idiarrina, de Santa Isabel do Morro, à esquerda, e Tohobari, de Bdè-Burè, à direita, assinam autorização para a realização da pesquisa. 


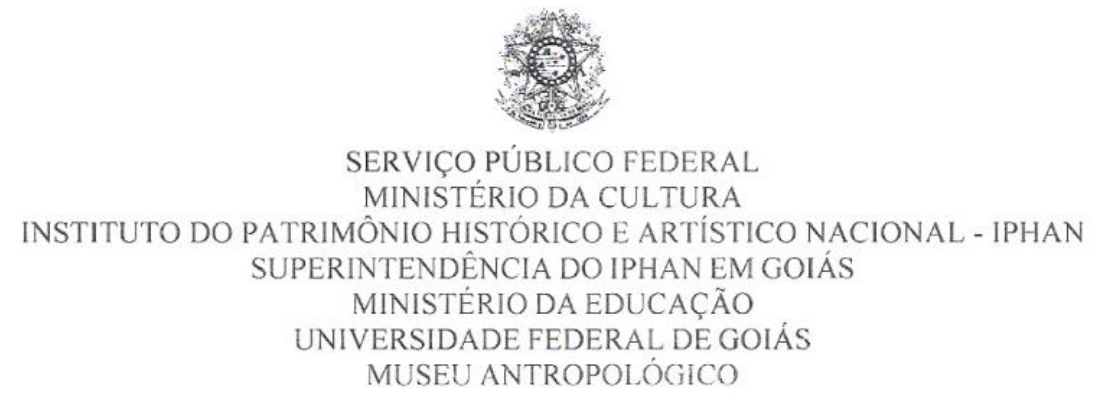

TERMO DE AUTORIZAÇÃO DE uso de IMAGEM

Pelo presente instrumento,

inscrito no CPF sob o número e no RG sob o número residente e domiciliado na Acrando neste ato denominado

AUTORIZANTE, outorga o seguinte termo de autorização:

1. O AUTORIZANTE autoriza a captação, fixação e utilização de sua imagem e de todos os elementos que a compõem para fins de pesquisa, elaboração de produtos e divulgação de projetos desenvolvidos pelo Instituto do Patrimônio Histórico e Artístico Nacional (IPHAN/MINC).

2. O IPHAN é uma instituição sem fins lucrativos que tem por objetivo a elaboração de políticas de salvaguarda, pesquisas e produtos que protejam, valorizem e divulguem o patrimônio cultural do Brasil.

3. A imagem autorizada poderá compor obra impressa ou audiovisual, a ser distribuída e exibida, por todo e qualquer veículo, processo, ou meio de comunicação e publicidade, existentes ou que venham a ser criados, notadamente, mas não exclusivamente, Bases de dados, mídia impressa, em cinema, teledifusão, home vídeo, DVD, CD-ROM, sítios da internet,em exibições públicas e privadas, assim como na divulgação e/ou publicidade do audiovisual em rádio, cinema e televisão, para exibição público ou domiciliar, reprodução no Brasil ou no exterior, exibições em festivais ou outros meios que se fizerem necessários

4. A presente autorização é firmada em caráter gratuito, por prazo indeterminado, pelo que nenhum pagamento será devido pelo Iphan ao AUTORIZANTE, a qualquer tempo e título.

IPHAN

RUA 84, N.61, QD F-15, LT .3 - SETOR SU1

FONE/FAX: (062) 3224-6402

$74.080 .400-$ GOIÂNIA - GO
MUSEU ANTROPOLÓGICO DA UFG

AV. UNIVERSITARIA, 1166 -SETOR UNIVERSITARIO FONES: (062) 3209-6010/3209-601

74.605.010 - GOIÂNIA - GO 
5. Esta autorização poderá ser suspensa pelo AUTORIZANTE: (1) por descumprimento de qualquer condição estabelecida neste instrumento; (2) por acordo entre as partes; (3) na superveniência de norma legal obstativa.

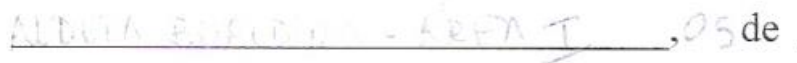
de 20

\section{AUTORIZANTE}

TÍTULO DA PROJETO: Bonecas Karajá: arte, memória e identidade indígena no Araguaia

\section{EQUIPE RESPONSÁVEL PELA PESQUISA}

Dra. Telma Camargo da Silva (Coordenadora da segunda fase da pesquisa)

Ms. Maira Torres Corrêa (representante do IPHAN na pesquisa)

Dr. Manuel Ferreira Lima

Dra. Rosani Moreira Leitão

Michelle Nogueira Resende (bolsista)

Nome e assinatura do/da pesquisadora em campo, responsável pelo preenchimento desse formulário:

Imagem 04 - Termo de Autorização Individual. 
REGISTRO FOTOGRÁFICO E A DINÂMICA DAS NEGOCIAÇÕES...

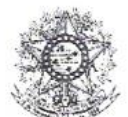 \\ SERVIÇO PÚBLICO FEDERAL \\ MINISTÉRIO DA CULTURA \\ INSTITUTO DO PATRIMÔNIO HISTÓRICO E ARTISTICO NACIONAL - IPHAN \\ SUPERINTENDÊNCIA DO IPHAN EM GOIÁS \\ MINISTÉRIO DA EDUCAÇÃO \\ UNIVERSIDADE FEDERAL DE GOIÁS \\ MUSEU ANTROPOLÓGICO
}

\title{
TERMO DE AUTORIZAÇÃO DE uso de IMAGEM
}

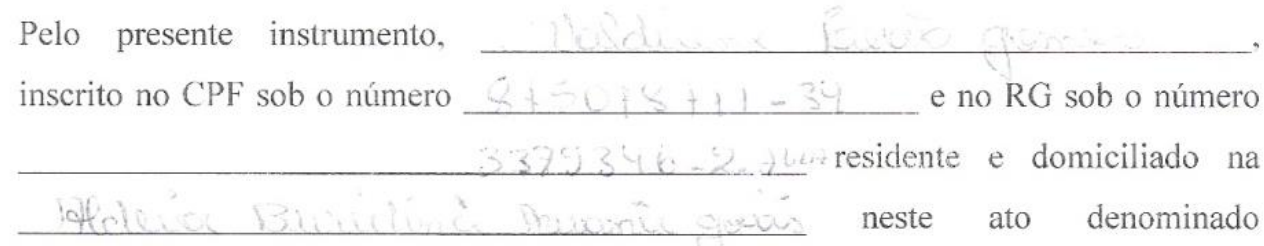

AUTORIZANTE, outorga o seguinte termo de autorização:

1. O AUTORIZANTE autoriza a captação, fixação e utilização de imagens tomadas coletivamente e de todos os elementos que as compõem para fins de pesquisa. elaboração de produtos e divulgação de projetos desenvolvidos pelo Instituto do Patrimônio Histórico e Artístico Nacional (IPHAN/MINC).

2. O IPHAN é uma instituição sem fins lucrativos que tem por objetivo a elaboração de politicas de salvaguarda, pesquisas e produtos que protejam, valorizem e divulguem o patrimônio cultural do Brasil.

3. A imagem autorizada poderá compor obra impressa ou audiovisual, a ser distribuída e exibida, por todo e qualquer veículo, processo, ou meio de comunicação e publicidade, existentes ou que venham a ser criados, notadamente, mas não exclusivamente, Bases de dados, mídia impressa, em cinema, teledifusão, home vídeo, DVD, CD-ROM, sítios da internet,em exibições públicas e privadas, assim como na divulgação e/ou publicidade do audiovisual em rádio, cinema e televisão, para exibição público ou domiciliar, reprodução no Brasil ou no exterior, exibições em festivais ou outros meios que se fizerem necessários

4. A presente autorização é firmada em caráter gratuito, por prazo indeterminado, pelo que nenhum pagamento será devido pelo Iphan ao AUTORIZANTE, a qualquer tempo e título.

IPHAN

RUA 84, No61, QD F-15. LT . 3 -SETOR St:1

FONE/FAX: (062) 3224-6402

74.080.400 - GOIÂNIA - GO
MUSEU ANTROPOLOGICO DA UFG

AV. UNIVERSITARIA, 1166 - SETOR LNIVERSITARIO FONES: $(062) 3209-6010 / 3209-6011$ 74.605.010-GOIÂNIA - GO 
5. Esta autorização poderá ser suspensa pelo AUTORIZANTE: (1) por descumprimento de qualquer condição estabelecida neste instrumento; (2) por acordo entre as partes; (3) na superveniência de norma legal obstativa.

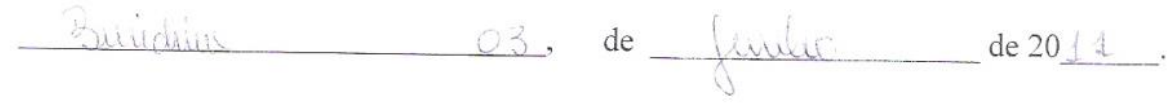

AUTORIZANTE

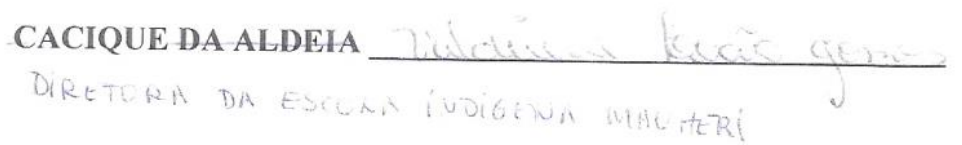
TÍTULO DA PROJETO: Bonecas Karajá: arte, memória e identidade indigena no
Araguaia

\section{EQUIPE RESPONSÁVEL PELA PESQUISA}

Dra. Telma Camargo da Silva (Coordenadora da segunda fase da pesquisa)

Ms. Maíra Torres Corrêa (representante do IPHAN na pesquisa)

Dr. Manuel Ferreira Lima

Dra. Rosani Moreira Leitão

Michelle Nogueira Resende (bolsista)

Nome e assinatura do/da pesquisadora em campo, responsável pelo preenchimento desse formulário:

Imagem 05 - Autorização Coletiva - Nesse exemplo assinada pela diretora da escola, pois envolvia uma atividade coletiva (oficina de cerâmica) - com as crianças alunas da Escola Mahueri - Aldeia Buridina.

Contudo, a dinâmica própria das interações em campo e das particularidades culturais do próprio grupo, engendraram tensões e demandaram negociações contínuas. O registro fotográfico expõe essa dinâmica não contemplada nos termos dos Comitês de Ética em Pesquisa, na forma como estipulada pela Resolução $n^{\circ} 196$, de 1996, do Ministério da Saúde. As notas aqui apresentadas são ao mesmo tempo uma descrição da fusão das etapas de autorização, captação e devolução das imagens fotográficas e uma contribuição às reflexões que problematizam o caráter tecnicista e biologizante dessa 
regulamentação que não abarca os diálogos, negociações e argumentações inerentes à construção da etnografia.

O uso que fiz da fotografia como metodologia seguiu duas direções distintas, porém complementares. À maneira de Bronislaw Malinowski nas suas pesquisas nas ilhas do Pacífico, no início do século XX - como apontado por Samain (1995) - houve um planejamento prévio sobre as fotografias a serem feitas. O meu interesse estava na execução do oficio, na descrição dos modos de fazer a Ritoxko, nas diferentes fases do processo de produção, com ênfase no uso do corpo das ceramistas. Como resultado, parte das imagens tem foco no gestual das oleiras ao longo do dia a dia de seu trabalho. Essa perspectiva de apreensão revela forte influência dos trabalhos de Mauss (1966), como na imagem reproduzida a seguir:

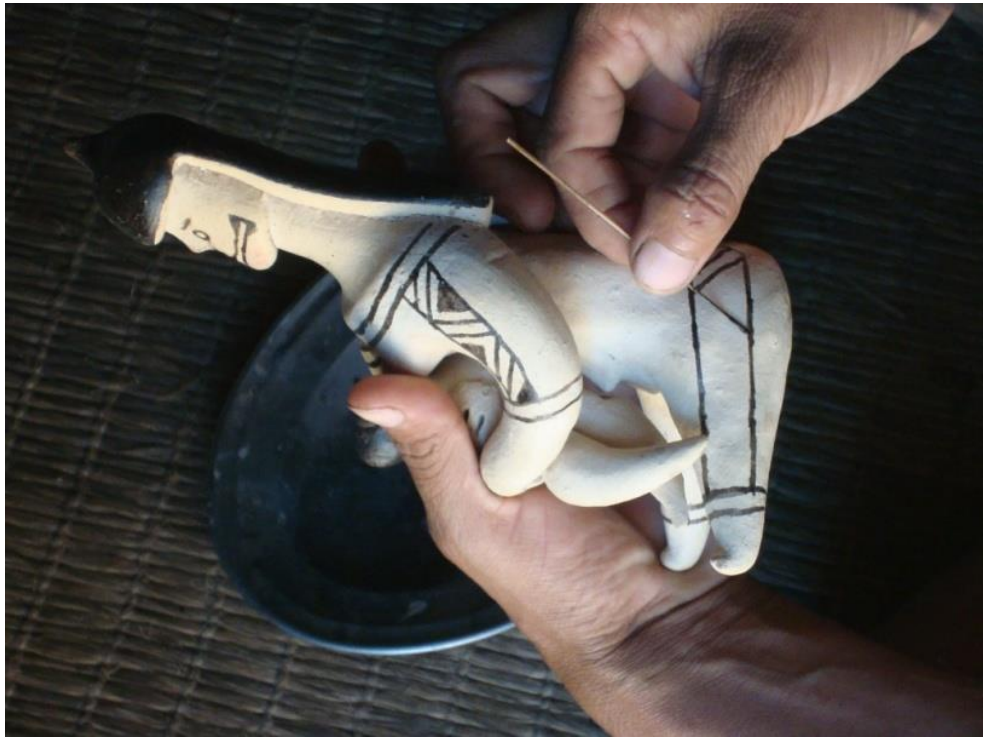

Imagem 06 - Gestual - o uso dos dedos no manuseio do pincel: Mahiru, ceramista de Santa Isabel do Morro, desenha os grafismos na Ritxoco.

Mas as imagens também compuseram o meu "diário iconográfico", registrando o cotidiano vivenciado pelos habitantes da aldeia em seus espaços de sociabilidades. $\mathrm{O}$ olhar aqui foi além do plano previamente estabelecido e registrou aquilo que fica entre a emoção - a sensibilidade - e o olhar disciplinado pelo treinamento antropológico. Cenas de rituais, as atribuições de gênero, os adornos corporais, as relações inter-geracionais 
foram temas apreendidos nesse registro fotográfico. A câmera acompanhou o ritmo e a temporalidade das pessoas nas suas vivências diárias.

Minha experiência com a construção de um "diário iconográfico" começou no início na década de oitenta quando estive entre os $\mathrm{Kraho}^{10}$, na aldeia do Rio Vermelho, então situada no Estado de Goiás. As mudanças tecnológicas ocorridas nos últimos anos e o tempo de permanência em campo particularizam estas duas experiências no que se refere à interação com os/as interlocutoras e ao processo de devolução do material fotográfico. Na experiência Krahó, eu utilizei uma máquina Nikon analógica, permaneci em campo durante um período contínuo e não mais retornei a esta área indígena. $O$ equipamento profissional, de certa forma, se interpunha entre a antropóloga e seus interlocutores e as fotos impressas foram devolvidas aos Krahó via mensageiro. Nesse sentido, as fases de autorização (verbal), captação e devolução foram executadas separadamente e de forma bastante distinta uma da outra.

$\mathrm{O}$ uso de uma máquina digital de pequeno tamanho ${ }^{11}$ inserida no bolso de um colete, usada na minha experiência de campo com o povo Karajá, me parece menos perturbadora. Além disso, a acessibilidade da fotografia digital, via uso do telefone celular, desmistificou a captação da imagem para muitos dos meus interlocutores, o que ainda não era o caso para os Krahó. A tecnologia digital contribuiu também para a diluição da separação entre as fases da captação e devolução das fotografias, pois em muitos casos, pude simultaneamente fotografar e mostrar para a pessoa fotografada a sua imagem. Este foi um elemento importante no processo de construção da interação com as mulheres ceramistas, principalmente para facilitar e estabelecer uma comunicação dificultada pelas barreiras linguísticas. Quando da devolução das fotografias impressas em papel, em meus vários retornos ao território Karajá, esse diálogo em muitos casos foi intensificado e a intimidade aprofundada, como pode ser interpretado pelos sorrisos e olhares expressos nas imagens abaixo:

\footnotetext{
${ }^{10}$ As imagens desse "diário iconográfico" subsidiaram a redação do diário de campo (Lazarin: Silva, 1989) e foram usadas como ilustração dessa publicação. A edição do material fotográfico constituiu dois ensaios, entendidos como narrativas visuais e representação de mulheres Krahó (Silva, 1986 A; 1986 B).

${ }^{11}$ Uma Sony - Cyber-shot; 13,6 mega-pixels; Lente Carl Zeiss; Vario-Tessar (2,8 - 5,5/7,6-22,8).
} 


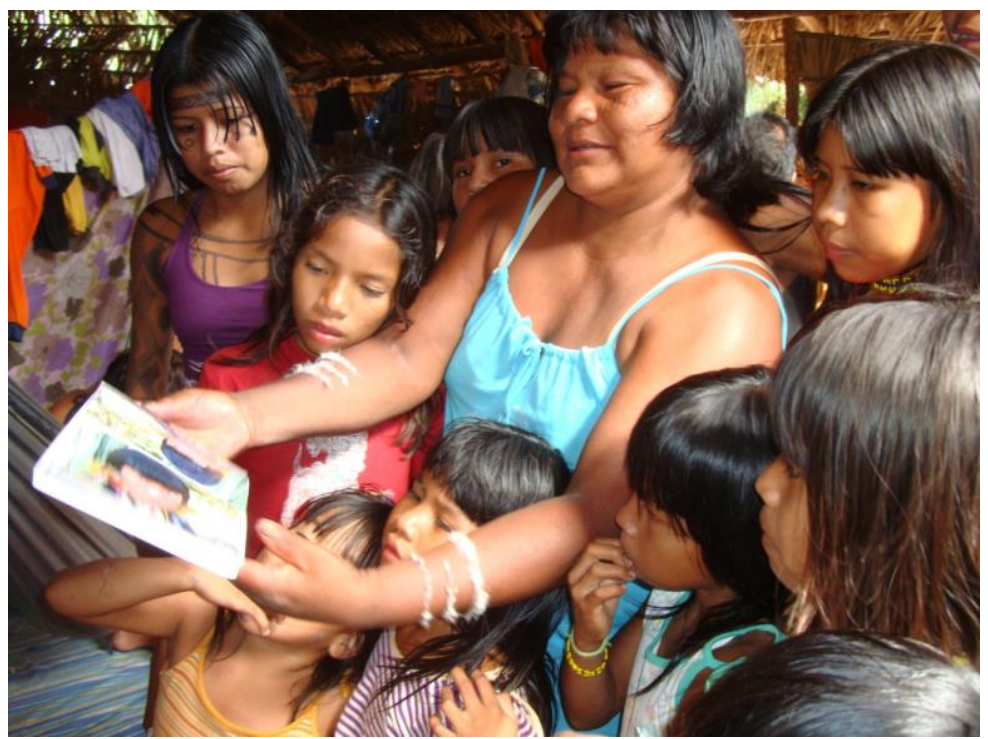

Imagem 07 - Devolução de imagens impressas para familiares da ceramista Idjanaro, da Aldeia Santa Isabel do Morro.
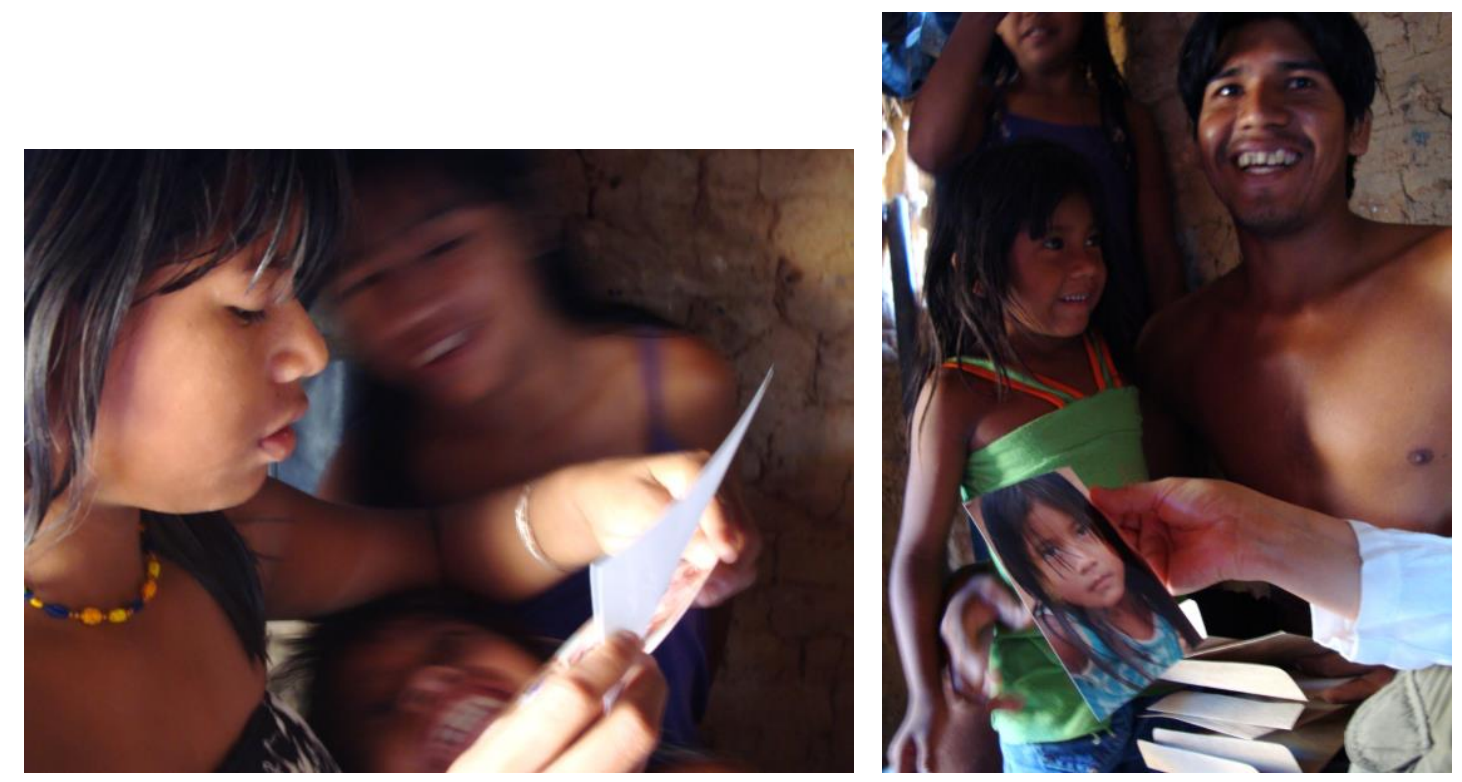

Imagens 08 e 09 - Devolução de fotos para familiares da ceramista Mahiru, de Santa Isabel do Morro. Na foto à direita, Creheluri, seu esposo.

$* * *$

Em outras situações, a devolução de fotos coletivas - algumas registradas em contextos ritualísticos - provocou mal-estar e implicou em novas articulações e negociações para a continuidade dos registros, independente da assinatura no TCLE já ter sido feita. Minha experiência com Maria ${ }^{12}$, narrada a seguir, ilustra uma dessas

\footnotetext{
${ }^{12}$ Por questões éticas, faço uso de pseudônimo e escolhi um nome não-iny.
} 
tensões. Maria foi uma das primeiras ceramistas contatas na pesquisa. Ela é reconhecida por pessoas da aldeia e, externamente, por outros pesquisadores como uma "ceramista mestra" (Lima et al., 2011: 101-102). Ela é grande conhecedora dos mitos relacionados às figuras modeladas em cerâmica e por isto uma grande narradora de estórias. Durante parte do trabalho de campo, Maria monopolizou a transmissão do "saber-fazer" a boneca e centralizou, por esta razão, as atenções da equipe de pesquisa tanto como figura central na rede de interlocução, trazendo as ceramistas de sua rede familiar para serem ouvidas, como receptora dos contra-dons envolvidos: presentes materiais como miçangas, enxadão para cavar o barro usado na produção de cerâmica; ajuda financeira para atividades ritualísticas, e venda de bonecas para os integrantes da equipe. No entanto, uma jovem ceramista interrompe esta esfera de domínio de Maria na transmissão da informação ao chamar a atenção dos/das pesquisadores para outras ceramistas-mestras, que não tinham a capacidade de articulação com a sociedade nãoíndia e por isto estavam até aquele momento "invisíveis". Uma nova rede de interlocutoras é formada e a centralidade e hegemonia de Maria na transmissão de conhecimento para a equipe de pesquisa enfraquecida. A esse fato, outro acontecimento contribui para desestabilizar ainda mais as relações e para a instalação do conflito. A família de Maria foi uma das responsáveis pelo Ritual do Hetohoky ${ }^{13}$ cujos momentos finais foram assistidos e fotografados em uma das minhas idas ao campo. Quando retorno a esta aldeia, eu mostro as imagens para Maria, mas entrego as fotos para o ixydinodu - o líder ritualístico ${ }^{14}$. Este ato, de certa forma ingênuo de minha parte, pois não considerei as disputas familiares subjacentes, exaltou os ânimos, desencadeou diálogos acirrados e a manifestação velada de não mais participação na pesquisa. A superação desse drama social (Turner, 1974: 3; 37-41) engendrado na produção da etnografia envolveu muita negociação e a promessa de envio de outra coleção de fotografias, que entreguei pessoalmente para Maria no meu retorno ao campo.

Em uma sociedade ${ }^{15}$ em que os grupos familiares são bem distintos e as disputas estruturais e em que o poder político feminino se instaura a partir dos espaços domésticos - lugar de produção e predominantemente de comercialização da Ritxoko -

\footnotetext{
${ }^{13}$ Ritual de iniciação masculina (Lima Filho, 1994).

${ }^{14}$ Ixydinodu, o chefe das festas "... elemento mediador entre o social e o sagrado, entre os homens e os Worysy (os mortos) e entre os homens e as mulheres." (Lima Filho, Id., p. 167)

${ }^{15}$ Os Karajá, como outros povos Jê do Brasil Central - Krahó, Xerente e Xavante - possuem uma organização social e cultural centrada nos grupos familiares e apresentam o princípio da uxorilocalidade (matrilocalidade). Este arranjo familiar interligado a uma forma preferencial de residência institui uma tensão entre os homens de uma mesma geração e entre sogra e genro. (Lima et al., 2011: 177).
} 
a entrada de novos atores sociais na rede social centralizada na pessoa de Maria é fator de desequilíbrio interno e agente desestabilizador na relação com a equipe de pesquisa. Esta tensão, no entanto, só se revela e é explicitada no ato de devolução da imagem fotográfica. Este caso reafirma também meu argumento de que a pesquisa Bonecas Karajá evidencia a dinâmica da interrelação entre autorização, produção e devolução da qual decorre contínua necessidade de negociação para a captação de imagens, independente do atendimento às formalidades de assinaturas de formulários para cessão de imagem.

\section{Fotografia como metodologia para o inventário dos grafismos aplicados nas Ritxoco}

As bonecas cerâmicas constituem um dos vários suportes nos quais os Karajá exercitam a arte do grafismo elaborada com motivos geométricos. Os estudos etnográficos consultados durante a realização desta pesquisa apontavam para o fato de que um mesmo padrão gráfico recebia um nome distinto de acordo com os informantes consultados (Costa, 1978). Esta constatação sugeria que a denominação acompanhava a perspectiva do olhar e da percepção do sujeito narrador, ocorrendo as "associações variáveis" (Boas, apud Costa. Id. p. 114). Estas múltiplas nominações colocavam questões para o processo analítico: o nome apontado se referia ao conjunto ou a partes do grafismo? Qual a subjetividade do/da informante ao nomear o desenho? Os desenhos fazem alusão a animais, vegetais, acidentes geográficos da mesma forma que os grafismos aplicados na pintura corporal e nos trançados das cestarias? A relação com flora, com a fauna, com um movimento e/ou com um animal é feita com partes ou com o todo do elemento referenciado?

Para responder estas questões, propus a elaboração de um catálogo de imagens, reproduzindo fotograficamente os grafismos das bonecas. Esse documento seria então levado a campo para que diferentes ceramistas fizessem a identificação (Silva. Julho Outubro de 2010) ${ }^{16}$. Esta estratégia preencheria outra lacuna que era a ausência conjunta $^{17}$ de imagens e a especificação dos nomes nos estudos com temática focada no grafismo das bonecas cerâmicas.

\footnotetext{
${ }^{16}$ Estas observações e estratégias metodológicas foram retomadas em Lima Filho; Silva. 2012.

${ }^{17}$ O trabalho de Costa (1978) apresenta um inventário de nomes, mas não as imagens correspondentes; o de Toral (1992) traz um inventário ilustrado de nomes, contudo focaliza a pintura corporal; e o Saviola (1995) reproduz em desenhos, feitos por Marco Mastroiani, os grafismos das bonecas integrantes da
} 
Assim vinte e sete bonecas, confeccionadas por diferentes ceramistas de Santa Isabel do Morro, trazidas para o Museu Antropológico pelos integrantes desta equipe de pesquisa, foram fotografadas por mim. Cada artefato, com identificação da ceramista e da temática reproduzida, foi fotografado no todo e, em seguida, fotografados os detalhes dos grafismos aplicados em diferentes partes do corpo. As imagens foram inseridas em uma planilha criada com a finalidade de ser impressa e levada a campo para obtenção dos nomes relativos aos padrões fotografados. O catálogo foi mostrado às ceramistas e os nomes anotados. Mais uma vez, o auxilio de intérpretes se fez necessário. Nesta ocasião, não só na comunicação verbal, mas também na grafia das palavras Karajá.

Abaixo exemplo de uma das planilhas, onde a imagem fotográfica foi usada como geradora de informação:

\section{$* * *$}

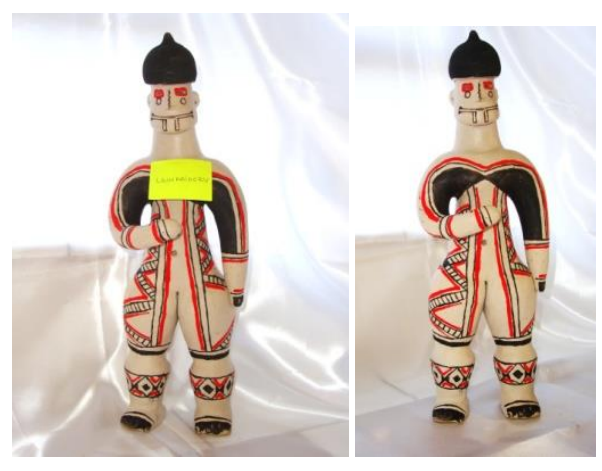

Ceramista: Lawarideru Tema: Guerreiro Teribré

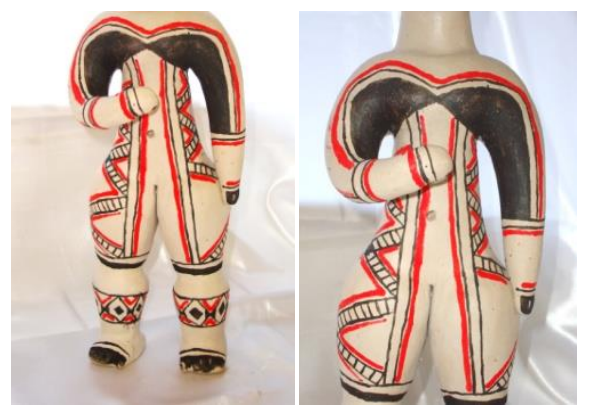

Frente

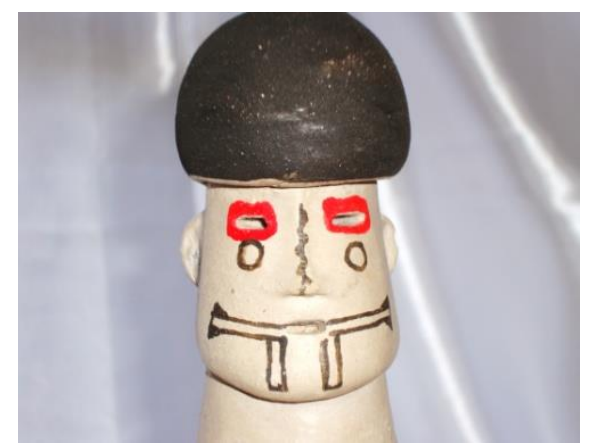

Ceramista: Lawarideru Tema: Guerreiro Teribré

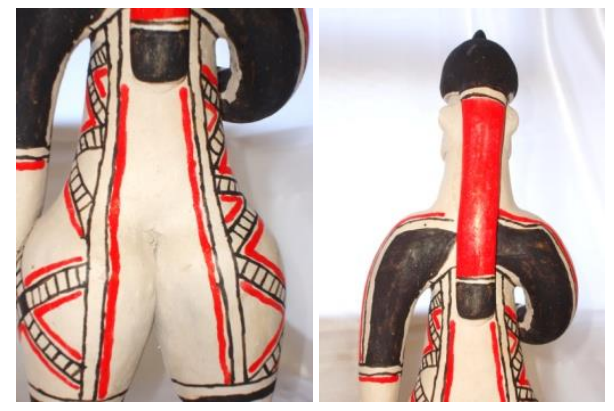

Costas

coleção pertencente ao Museo Nazionale Preistorico Etnografico Luigi Pigorini (Roma-Itália), mas não identifica os padrões gráficos. 
REGISTRO FOTOGRÁFICO E A DINÂMICA DAS NEGOCIAÇÕES..

\begin{tabular}{|c|c|c|c|c|c|c|}
\hline $\begin{array}{l}\text { LOCALIZAÇÃO } \\
\text { DO GRAFISMO }\end{array}$ & $\begin{array}{l}\text { NOME DO } \\
\text { PADRÃO: }\end{array}$ & SIGNIFICADO & $\begin{array}{c}\text { NOME } \\
\text { DA INFORMANTE }\end{array}$ & ALDEIA & DATA & $\begin{array}{c}\text { LOCAL DE } \\
\text { COLETA DA } \\
\text { INFORMAÇÃO } \\
\text { E NOME } \\
\text { DA } \\
\text { PESQUISADOR } \\
\text { A } \\
\end{array}$ \\
\hline \multirow[t]{5}{*}{$\begin{array}{c}\text { PEITORAL } \\
\text { (Frente) } \\
\text { COSTAS } \\
\text { (grafismo que passa } \\
\text { pela parte superior e } \\
\text { desce pelos braços) }\end{array}$} & $\begin{array}{c}\text { Wariri } \\
\text { (nas pessoas é } \\
\text { usado somente } \\
\text { para homens) }\end{array}$ & Tamanduá & $\begin{array}{l}\text { 1)Iracema Hakótí } \\
\text { Karajá } \\
\text { 2)Hamunjaka } \\
\text { (filho de Iracema) }\end{array}$ & $\begin{array}{l}\text { 1)Itxalá } \\
\text { 2)Itxalá - } \\
\text { Sta. } \\
\text { Terezinha } \\
\text { (MT) }\end{array}$ & $\begin{array}{c}31 \text { de } \\
\text { maio } \\
\text { de } \\
2010\end{array}$ & $\begin{array}{c}\text { Museu } \\
\text { Antropológico } \\
\text { Telma Camargo } \\
\text { da Silva }\end{array}$ \\
\hline & Itxalabu & & $\begin{array}{c}\text { Mahuederu } \\
\text { Mawisi (filho de } \\
\text { Mahuederu auxiliou na } \\
\text { tradução e na grafia) }\end{array}$ & $\begin{array}{c}\text { Santa } \\
\text { Isabel do } \\
\text { Morro (TO) }\end{array}$ & $\begin{array}{c}12 \text { de } \\
\text { junho } \\
\text { de } \\
2010\end{array}$ & $\begin{array}{c}\text { Aldeia de Sta. } \\
\text { Isabel do Morro } \\
\text { Telma Camargo } \\
\text { da Silva }\end{array}$ \\
\hline & Isalybá & & $\begin{array}{c}\text { Lawarideru } \\
\begin{array}{l}\text { Korihele (auxiliou na } \\
\text { tradução e na grafia) }\end{array}\end{array}$ & $\begin{array}{c}\text { Santa } \\
\text { Isabel do } \\
\text { Morro (TO) }\end{array}$ & $\begin{array}{l}13 \text { de } \\
\text { junho } \\
\text { de } \\
2010\end{array}$ & $\begin{array}{c}\text { Aldeia de Sta. } \\
\text { Isabel do Morro } \\
\text { Telma Camargo } \\
\text { da Silva }\end{array}$ \\
\hline & Ixalabu & Coité preto & Kaimoti & $\begin{array}{c}\text { Santa } \\
\text { Isabel do } \\
\text { Morro (TO) }\end{array}$ & $\begin{array}{l}132 \mathrm{de} \\
\text { junho } \\
\text { de } \\
2010 \\
\end{array}$ & $\begin{array}{l}\text { Aldeia de Sta. } \\
\text { Isabel do Morro } \\
\text { Nei clara de Lima }\end{array}$ \\
\hline & Ixalabu & $\begin{array}{c}\text { Coité preto } \\
\text { Pintura } \\
\text { corporal } \\
\text { masculina } \\
\text { usada no peito }\end{array}$ & $\begin{array}{c}\text { Coaxiro } \\
\text { Txirawa (auxiliou na } \\
\text { tradução e na grafia) }\end{array}$ & $\begin{array}{c}\text { Santa } \\
\text { Isabel do } \\
\text { Morro (TO) }\end{array}$ & $\begin{array}{c}12 \text { de } \\
\text { junho } \\
\text { de } \\
2010\end{array}$ & $\begin{array}{c}\text { Aldeia de Sta. } \\
\text { Isabel do Morro } \\
\text { Nei Clara } \\
\text { Rosani Leitão }\end{array}$ \\
\hline \multirow[t]{2}{*}{$\begin{array}{c}\text { COXA E TRONCO } \\
\text { (frente e costas e } \\
\text { lateral) }\end{array}$} & Tyheré-rokó & $\begin{array}{c}\text { Pintura do } \\
\text { morcego }\end{array}$ & $\begin{array}{l}\text { 1)Iracema Hakótí } \\
\text { Karajá } \\
\text { 2)Hamunjaka } \\
\text { (filho de Iracema) }\end{array}$ & $\begin{array}{l}\text { 1)Itxalá } \\
\\
\text { 2)Itxalá - } \\
\text { Sta. } \\
\text { Terezinha } \\
\text { (MT) }\end{array}$ & $\begin{array}{c}31 \mathrm{de} \\
\text { maio } \\
\text { de } \\
2010\end{array}$ & $\begin{array}{c}\text { Museu } \\
\text { Antropológico } \\
\text { Telma Camargo } \\
\text { da Silva }\end{array}$ \\
\hline & Haru & & $\begin{array}{c}\text { Mahuederu } \\
\text { Mawisi (filho de } \\
\text { Mahuederu auxiliou na } \\
\text { tradução e na grafia) }\end{array}$ & $\begin{array}{c}\text { Santa } \\
\text { Isabel do } \\
\text { Morro (TO) }\end{array}$ & $\begin{array}{c}12 \text { de } \\
\text { junho } \\
\text { de } \\
2010\end{array}$ & $\begin{array}{c}\text { Aldeia de Sta. } \\
\text { Isabel do Morro } \\
\text { Telma Camargo } \\
\text { da Silva }\end{array}$ \\
\hline
\end{tabular}

Planilha 1 - Silva, Julho - Outubro de 2010, p. 24 - 26.

O uso da imagem fotográfica das bonecas, com foco nos grafismos, foi um recurso que permitiu viabilizar o registro de aspectos formais e sua identificação pelas ceramistas. Além desse aspecto metodológico na constituição de um inventário dos grafismos, a circulação do catálogo na aldeia Santa Isabel do Morro aprofundou a interação da equipe de pesquisa com um número maior de mulheres e atuou como préprodução para a fase de filmagem, segunda etapa da pesquisa. Este documento motivou também conversas e trocas de experiências entre as próprias ceramistas que ao olharem as imagens fotográficas expressavam suas apreciações ou não sobre a qualidade e a 
criatividade do trabalho da ceramista ali registrado. Se o padrão gráfico não estava aplicado de forma uniforme e retilínea, o comentário era: "Ela [a ceramista que fez a boneca] é uma aprendiz".
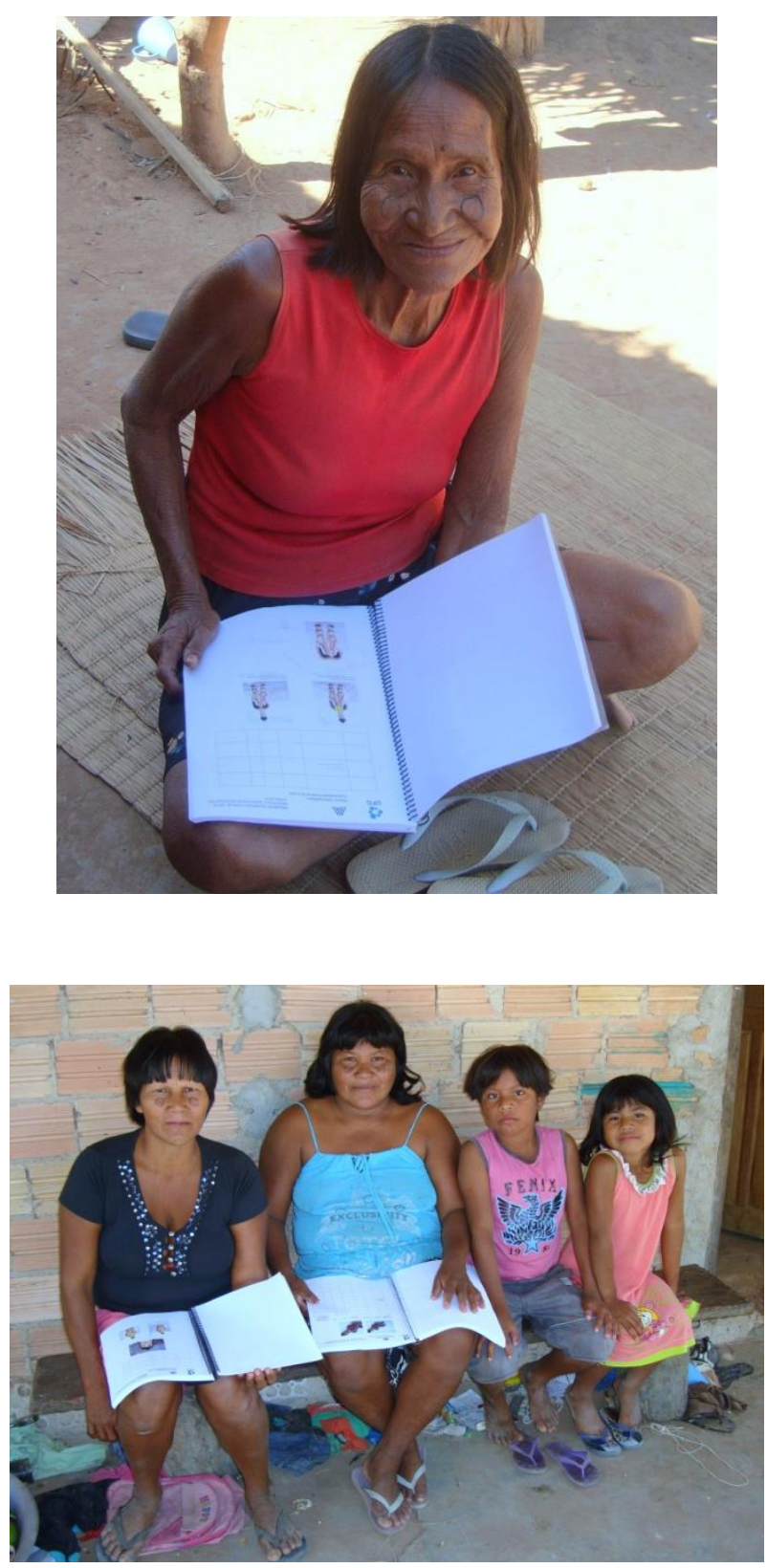

Imagem 10 e 11 - Circulação do catálogo entre as ceramistas da aldeia Santa Isabel do Morro. Àcima a Lawarideru. Na foto abaixo, Heredike e Idjanaru e suas crianças. 
A circulação do catálogo e os encontros no interior das moradias também oportunizaram a inserção de um conjunto de pessoas que até então não estavam inseridas como interlocutoras na produção de conhecimento sobre os modos de fazer a boneca e suas significações: as crianças. No momento em que o preenchimento da planilha aconteceu na casa de Mahiru - que também reproduziu em papel os motivos gráficos usados por ela em suas ritxoko - as meninas de sua família extensa pediram papel e caneta e também desenharam. Com a ajuda da avó materna nomearam os grafismos riscados nas cores vermelha e preta sobre papel branco (Silva, Julho Agosto. 2010. p. 89 - 92). São estas crianças que posteriormente tem as imagens de suas brincadeiras com as famílias de bonecas captadas no vídeo Ritxoko. Este fato ilustra uma vez mais que o próprio desenrolar da pesquisa introduz novos atores sociais na dinâmica da interlocução em campo e nem todos previstos no projeto inicial. Logo, por um lado, esta experiência evidencia que nem todas as autorizações para uso de imagem são assinadas no início da pesquisa. Por outro, reafirma as constantes negociações que engendram esta fusão entre autorização, captação e devolução argumentada por mim nesse artigo.

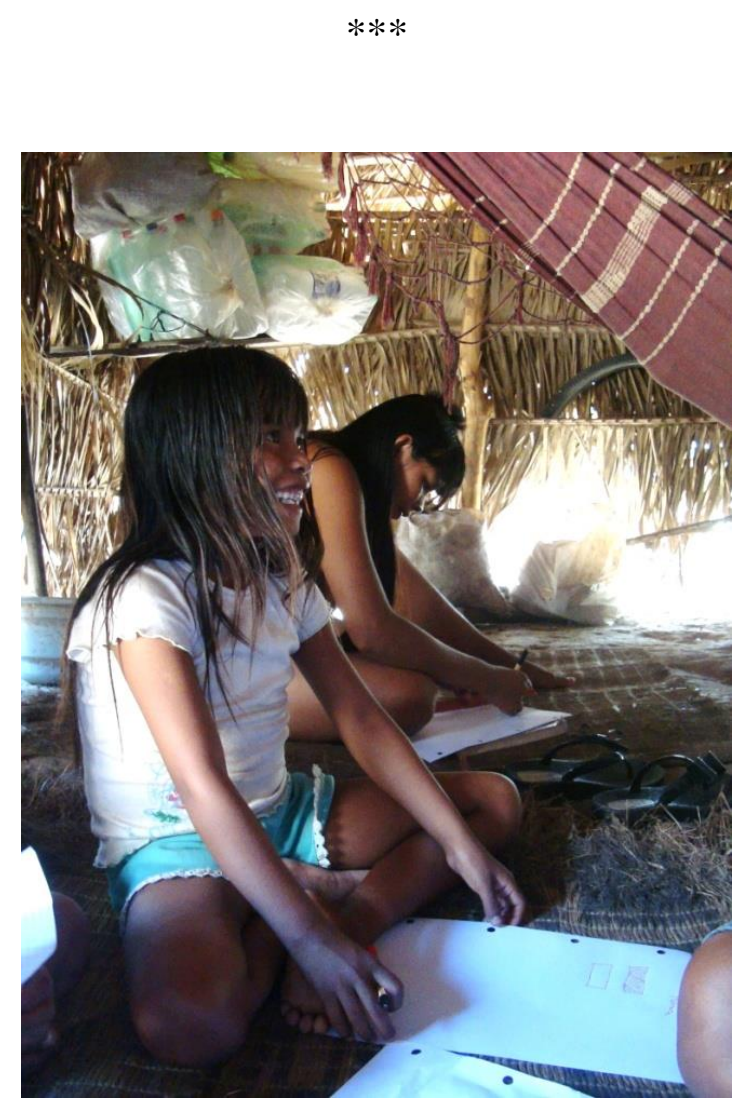

Imagem 12 - Habearu e Narubia reproduzem, em papel, os grafismos. 


\section{Ambiguidades no olhar: fotografia e registro da subjetividade}

As pequenas $^{18}$ bonecas cerâmicas representando uma família extensa, presenteadas pelas avós a suas netas, são apontadas como o início da produção de ritxoko pelas ceramistas Karajá (Simões, 1992: 5; retomado em Lima, et al, 2011: 25). Essas "famílias" - objetos de brinquedo - condensam múltiplos atributos como agentes de sociabilização como, por exemplo: a aprendizagem sobre os papeis dos diferentes integrantes da família extensa; sobre os grafismos corporais identificadores de gênero e classe de idade e a constituição da pessoa Karajá e a iniciação na atividade de oleira (Campos, 2007; Lima et al,. 2011).
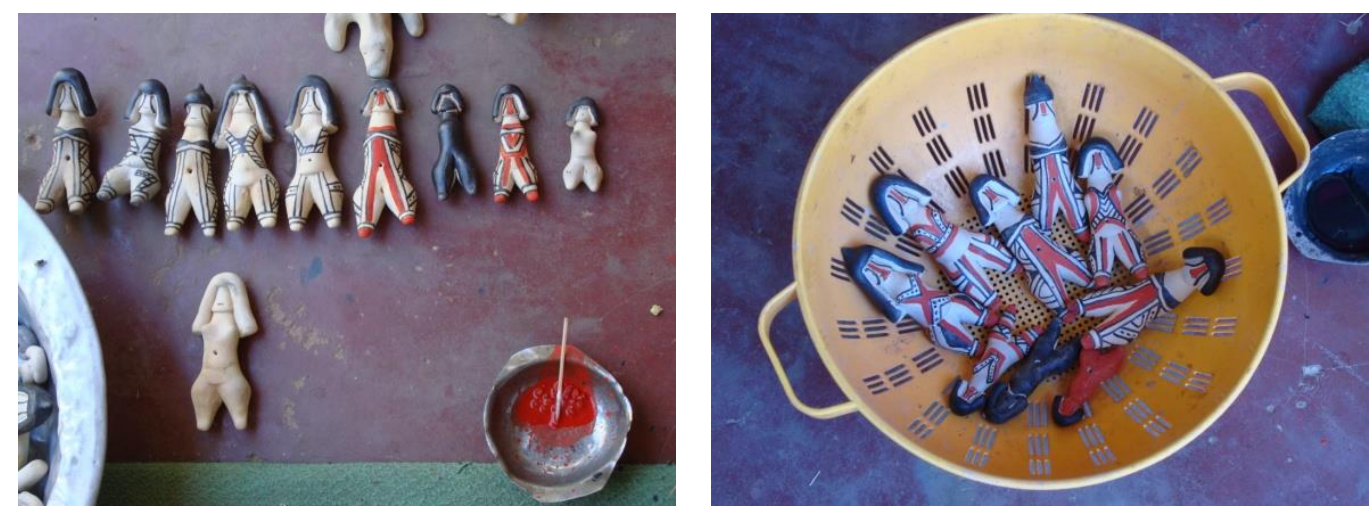

Imagens 13 e 14: Uma família modelada pela ceramista Komytira da aldeia Santa Isabel do Morro.

$* * *$

\footnotetext{
${ }^{18}$ Os tamanhos variam de $15 \mathrm{~cm}$ (adulto jovem) a $5 \mathrm{~cm}$, boneca representando um recém-nascido. As figuras que simbolizam os velhos (os avós) são modeladas com o corpo encurvado e tem a medida de 9 cm de altura, em média.
} 


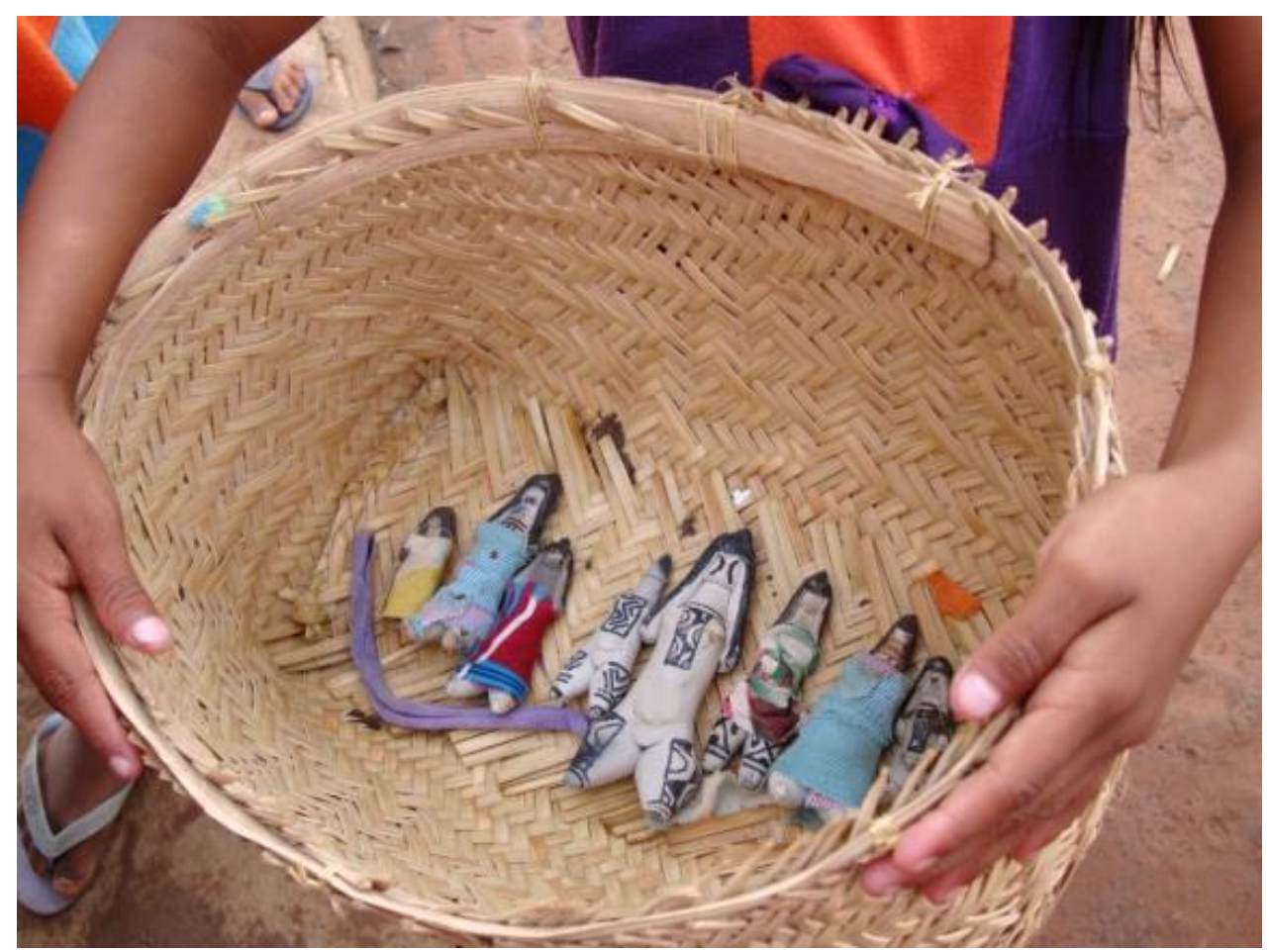

Imagem 15: Uma família, como artefato de brinquedo, são colocados em uma Wereri - a cesta confeccionada pelos avôs.

Os laços afetivos entre avó ${ }^{19}$ materna e netas, reforçados pelo principio da uxorilocalidade, são vivenciados no cotidiano do espaço doméstico, onde as bonecas cerâmicas são produzidas e, na maioria das vezes, comercializadas. Ter uma avó reconhecida como uma "boa ceramista" sugere que suas netas serão desde pequenas iniciadas na atividade de oleira. Koaxiro, moradora de Santa Isabel do Morro, se insere nessa classificação e entre as figuras temáticas que modela, o conjunto de família é uma de suas especialidades. Ela tem várias netas e, quando do registro fotográfico, estas meninas estavam sempre ao lado da avó, como Heryko (imagem 16). Informada pelas etnografias estudadas e pelas observações de campo o meu interesse em acompanhar o cotidiano de Koaxiro e Heryko era registrar o processo de transmissão intergeracional do conhecimento sobre o oficio de fazer bonecas-cerâmica. Assim, acompanhei Koaxiro e Heryko durante uns três dias e, ao final, as imagens captadas me sugeriam que a criança não havia interagido com a avó em nenhuma das fases de produção da boneca,

\footnotetext{
${ }^{19}$ Lahi na Língua Karajá.
} 
em que a ceramista esteve envolvida naquele período: modelagem, queima e pintura. Muitas das fotografias de Heryko mostravam um movimento de mãos e olhares que indicavam certo constrangimento e vergonha pelo fato de estar sendo fotografada (sequência 17, 18, 19). Em todas elas, outro elemento era constante nas imagens $\operatorname{captadas}^{20}$ : a presença de um conjunto de bonecas já queimadas, mas não ainda pintadas. Estas ritoxko sempre apareciam nas mãos ou ao lado da criança.

Da sequência de fotos, uma última fotografia me chamou a atenção e levantou dúvidas sobre o sugerido acanhamento por parte de Heryko em ser fotografada: ela me olha diretamente, através da câmera, e expõe - oferece ao olhar - as suas bonecas (Imagem 20). Converso com Dibexia, assistente Karajá no trabalho de campo, sobre as ambiguidades engendradas pela leitura dessas imagens. Então, outra narrativa surge. Dibexia relata que Heryko estava muito angustiada, com medo de que eu comprasse aquelas bonecas, as únicas figuras modeladas por sua avó naqueles dias como uma constituindo uma família. Por esta razão, ela sempre segurava nas mãos estas ritoxoko, encolhia o corpo quando eu me aproximava e desviava o olhar quando fotografada. Ela também não havia permitido que Koaxiro finalizasse a confecção, inserindo o grafismo, razão porque elas estão com as cores claras, resultado da segunda queima. Somente após a avó assegurar que estas bonecas não seriam vendidas e de presentear a neta com elas, Heryko fica tranquila e não mais desvia o olhar da minha câmera. O acordo entre avó e neta permite o registro da imagem em que a troca de olhares entre quem fotografa e quem é fotografada acontece diretamente (Imagem20). O olhar não mais é desviado.

\footnotetext{
${ }^{20}$ Ao final do dia, sempre olhava as fotografias captadas. Este processo permitia uma rápida análise ainda em campo e, quando necessário um redirecionamento do olhar. Contudo não transferia as imagens dos cartões para o computador. Esta era uma atividade de escritório, após o regresso do campo.
} 

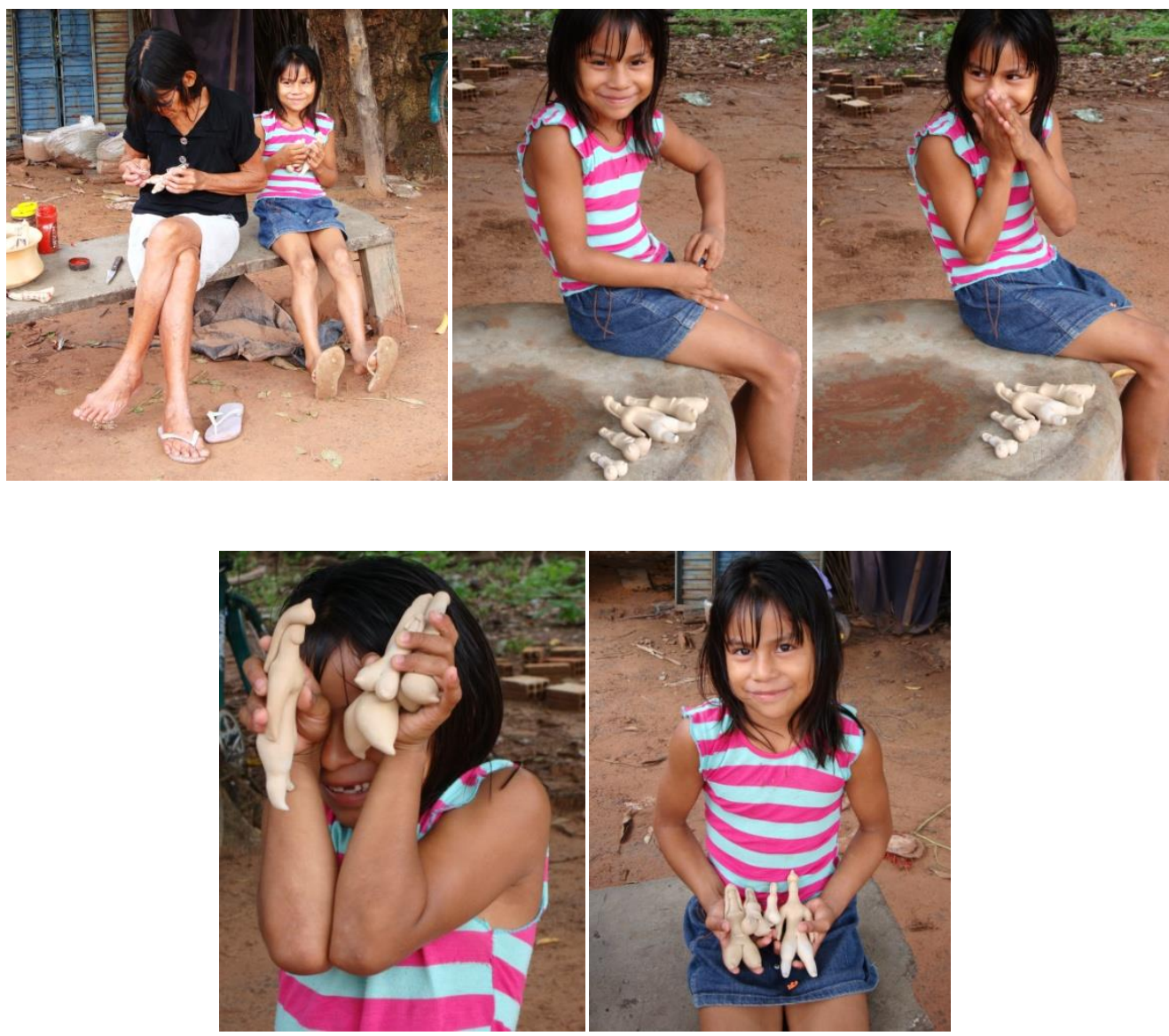

Sequências de imagens 16, 17, 18, 19, 20 - Ceramista Koaxiro e sua neta Heryko, da aldeia Santa Isabel do Morro.

Este relato sugere que o "diário iconográfico" não substitui o tradicional diário de campo em que as observações são anotadas. Eles são complementares e interdependentes $^{21}$. Mesmo que no processo de produção pós-campo estas imagens, sendo editadas, possam constituir uma narrativa visual ${ }^{22}$, elas são indissociáveis, enquanto captação em campo, das anotações escritas. Indica também que a fotografia, como outra forma de interação com os interlocutores, deve ser sempre acompanhada de conversas com os interlocutores sobre as situações vivenciadas. Minha experiência evidencia também que a produção da documentação visual, em pesquisas que objetivam a patrimonialização de referência cultura indígena, intensifica o processo de negociação e provoca a fusão entre as etapas de negociação, captação e devolução de imagens. Mas,

\footnotetext{
${ }^{21} \mathrm{Na}$ escrita etnográfica, na produção dos relatórios, as informações do meu "diário iconográfico" foram fundamentais na interpretação das situações vivenciadas em campo. Mais do que material ilustrativo - e as imagens tiveram também este uso - elas se constituíram em fontes de dados a serem interpretados.

${ }^{22} \mathrm{O}$ ensaio fotográfico As Ritxòkò do Araguaia: Arte das mulheres Karajá, exposto durante a reunião da Associação Nacional de Pós-Graduação em Ciências Sociais - ANPOCS, em 2010 seria um exemplo.
} 
a experiência com Heryko aponta também para o fato de que as emoções e as subjetividades de nossos e nossas interlocutores/as, expressas corporalmente, são melhores apreendidas pelo olhar fotográfico. Cabe à sensibilidade do/da pesquisador/a saber olhar e interpretar.

\section{Referências}

CAMPOS, Sandra Maria Christiani de la Torre Lacerda. Bonecas Karajá: modelando inovações, transmitindo tradições. 2007. (Tese de Doutorado) - Departamento de Ciências Sociais - Antropologia, PUC, São Paulo, 2007.

IPHAN - INSTITUTO DO PATRIMÔNIO HISTÓRICO E ARTÍSTICO NACIONAL. A786. Arte Kusiwa: pintura corporal e arte gráfica wajãpi. $2^{\mathrm{a}}$ Ed. Brasília: IPHAN, 2008.

Inventário nacional de referências culturais: manual de aplicação. Apresentação de Célia Corsino. Introdução de Antonio Augusto Arantes Neto. Brasília: IPHAN, 2000.

LAZARIN, Marco Antonio; SILVA, Telma Camargo da. Os Krahó do Rio Vermelho: Relatório de Trabalho. Textos para Discussão n.10. Goiânia: CEGRAF, UFG, 1989.

LIMA FILHO, Manuel Ferreira. Hetohoky: um rito Karajá. Goiânia: Ed. UCG, 1994.

LIMA FILHO, Manuel Ferreria; SILVA, Telma Camargo da. "A arte de saber fazer grafismo nas bonecas Karajá”. In: Horizontes Antropológicos, Ano 18, n.38, jul./dez. Porto Alegre: UFRGS, 2012. p. $45-74$.

LIMA, Nei Clara et. al. Bonecas Karajá: arte, memória e identidade indígena no Araguaia - Dossiê descritivo do modo de fazer ritxoko. Goiânia: Universidade Federal de Goiás/ Museu Antropológico, 2011.

MAUSS, Marcel. The Gift: Forms and Functions of Exchange in Archaic Societies. London: Cohen \& West Ltda., 1966 [1923 - 1924].

"As técnicas corporais". In: Sociologia e Antropologia. Vol. II. São Paulo:

Editora da Universidade de São Paulo. 1974 [1950]. p. 209 - 233.

NETO, Borges (Direção). Ritxoko - Vídeos documentários de 18 e 45`. Roteiro: Manuel Ferreira Lima Filho, Nei Clara de Lima, Neto Borges, Rosani Moreira Leitão e Telma Camargo da Silva. Trilha Sonora: Pedro Salles. Olho Filmes, Museu Antropológico, UFG, FUNAPE, IPHAN, Ministério da Cultura. 2011.

SAMAIN, Etienne. "Ver" e "dizer" na tradição etnográfica: Bronislaw Malinowski e a fotografia". In: Horizontes Antropológicos (Antropologia Visual) Ano 1, n.2. Porto Alegre: UFRGS, 1995. p. 19 - 48.

SAVIOLA. D. "I Karajá Dell Araguaia". In: NOBILI, C.; SAVIOLA, D. I segni Del tempo: arte, cultura e storia di ter etnie del Brasile. Catálogo de exposição, Museo Nazionale Preistorico Entnografico Luigi Pegorini. Roma: Edizioni Sean Roma, 1995. p. $45-47$.

SILVA, Telma Camargo da. Mulheres Mehin: um olhar fotograficamente amoroso. Exposição Temporária. Goiânia: Museu Antropológico / Centro de Estudos da Cultura Popular - CECUP, UFG. 1986 a.

"Mulheres Mehin: um olhar fotograficamente amoroso". In: Jornal Mulherio.

Ano VI, n. 25, mar/ago. São Paulo: Fundação Carlos Chagas ,1986 b. p. 12 -13. 
Primeiras aproximações ao grafismo aplicado às Ritxoko: Aldeia Santa Isabel do Morro (Hawaló) - Ilha do Bananal (TO). Relatório Técnico. Goiânia: Museu Antropológico, IPHAN, Julho - Outubro de 2010. (Circulação restrita)

"Mediação Antropológica em Processos de Registro de Bem Cultural". In: $28^{a}$ Reunião da Associação Brasileira de Antropologia - 28 $8^{a}$ RBA, 2012, São Paulo. Anais da $28^{a}$ RBA, v.1. Brasília: ABA, 2012 a. p. 1 - 6. Disponível em: http://www.abant.org.br/conteudo/ANAIS/CD_Virtual_28_RBA/index.html. Acesso em: 12 de dezembro de 2012.

. "Produção do Conhecimento e o campo político-intelectual: reflexões sobre cenários, atores sociais e mediações a partir de experiências com mapeamento e registro em projetos desenvolvidos no Museu Antropológico da UFG". In: $1^{o}$ Seminário de Patrimônio Imaterial: Entre Ofícios e Direitos. Goiânia: Museu Antropológico da UFG, 2012 b (não publicado).

SIMÕES, Mário Ferreira. Cerâmica Karajá e outras notas etnográficas. LIMA FILHO, Manuel Ferreira; NUNES, Maria Eugênia Brandão Alvarenga (Orgs). Goiânia: UCG Editora, 1992.

TURNER, Victor. Drama, Fields, and Metaphors: Symbolic Action in Human Society. Ithaca: Cornel University Press, 1974. 